\title{
Cooperative Interactions between Trichomonas vaginalis and Associated Bacteria Enhance Paracellular Permeability of the Cervicovaginal Epithelium by Dysregulating Tight Junctions
}

\author{
Annabel S. Hinderfeld, ${ }^{a}$ Niha Phukan, ${ }^{a *}$ Ann-Katrein Bär, ${ }^{a}$ Anthony M. Roberton, ${ }^{a}$ (D) Augusto Simoes-Barbosa ${ }^{a}$ \\ aschool of Biological Science, University of Auckland, Auckland, New Zealand
}

\begin{abstract}
The human protozoan Trichomonas vaginalis is the causative agent of trichomoniasis, a prevalent sexually transmitted infection, which is accompanied by a species-diversified vaginal microbiota named community state type IV (CST-IV). Coincidently, CST-IV includes species associated with bacterial vaginosis (e.g. Gardnerella vaginalis, Atopobium vaginae, and Prevotella bivia). Both diseases are linked to the transmission of human immunodeficiency virus (HIV) and preterm birth, which complications are likely to result from the disruption of the cervicovaginal epithelial barrier. Here, we show that paracellular permeability of fluorescein isothiocyanate (FITC)-dextran through a monolayer of human ectocervical cells (hECs) is increased as a consequence of the activity of $T$. vaginalis and the aforementioned species of CST-IV bacteria cooperatively. T. vaginalis enhances paracellular permeability of hECs two times more than the individual bacterial species, by up to $\sim 10 \%$ versus $\sim 5 \%$, respectively. However, any two or all three bacterial species are capable of synergizing this effect. T. vaginalis and the bacteria together increase the paracellular permeability of hECs by $\sim 50 \%$, which is 5 to 10 times more than the results seen with the protozoan or bacteria alone. This effect is accompanied by enhancement of phosphatase activity, while phosphatase inhibition results in preservation of the integrity of the ectocervical cell monolayer. In addition, these microorganisms induce changes in the expression of tight junction proteins, particularly occludin, and of proinflammatory cytokines interleukin-6 (IL-6) and tumor necrosis factor alpha (TNF- $\alpha$ ). Together, our findings establish that cooperative interactions between CST-IV bacteria and $T$. vaginalis enhance the paracellular permeability of the cervicovaginal epithelium by disturbing the integrity of the tight junction complex. Our study results highlight the importance of understanding the contribution of the vaginal microbiota to trichomoniasis.
\end{abstract}

KEYWORDS Trichomonas vaginalis, bacterial vaginosis, microbial cooperation, microbial synergism, paracellular permeability, phosphatase, tight junctions, vaginal epithelium, vaginal microbiota

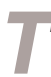
richomonas vaginalis is an extracellular protozoan that specifically parasitizes the human urogenital tract, causing trichomoniasis, the most common nonviral sexually transmitted disease worldwide (1). The vagina of premenopausal women is colonized by a specific microbiota that has been classified into five types (2). Four of these community state types (CSTs) are dominated by one species of Lactobacillus, specifically, Lactobacillus gasseri, L. crispatus, L. jensenii, or L. iners. The fifth CST (named CST-IV), however, is defined by the absence of lactobacilli and the overgrowth of anaerobic bacteria such as Gardnerella vaginalis, Atopobium vaginae, Prevotella bivia, and others (2). Although T. vaginalis infections have been associated with the CST-IV microbiota, this correlational observation does not necessarily imply causation (3).
Citation Hinderfeld AS, Phukan N, Bär A-K, Roberton AM, Simoes-Barbosa A. 2019. Cooperative interactions between Trichomonas vaginalis and associated bacteria enhance paracellular permeability of the cervicovaginal epithelium by dysregulating tight junctions. Infect Immun 87:e00141-19. https://doi.org/10 $.1128 /$ IAl.00141-19.

Editor De'Broski R. Herbert, University of Pennsylvania

Copyright $\odot 2019$ American Society for Microbiology. All Rights Reserved.

Address correspondence to Augusto SimoesBarbosa, a.barbosa@auckland.ac.nz.

* Present address: Niha Phukan, Caldera Health, Ltd., Auckland, New Zealand.

Received 17 February 2019

Accepted 7 March 2019

Accepted manuscript posted online 11

March 2019

Published 23 April 2019 
Coincidently, though, the aforementioned CST-IV bacterial species are also causative agents of bacterial vaginosis (BV) and this condition represents a risk for the acquisition of trichomoniasis (4).

These infections cause similar vaginitis-related symptoms (e.g., itching and a frothy malodorous discharge) and are associated with pathological complications such as preterm birth (5-10) and high transmissibility of human immunodeficiency virus (HIV) (11-14). CST-IV bacteria are known to induce physical, immunological, and biochemical changes in the cervicovaginal mucosa. For example, bacterial species of CST-IV promote a greater proinflammatory response in the vagina than lactobacillus-dominant communities $(9,15-18)$. In addition, these bacteria (particularly $G$. vaginalis) affect the integrity of cervicovaginal epithelial barrier $(10,17)$. Although these alterations are likely to contribute to the pathological complications that are similarly associated with both trichomoniasis and BV, such as poor pregnancy outcomes and HIV acquisition, it is unclear if BV-associated bacteria and T. vaginalis act cooperatively in promoting disease.

Microbial synergism has been described as representing cooperative activities resulting from the interaction of two or more microorganisms that produce an enhanced disease phenotype $(19,20)$. Microbiota may harbor indigenous pathobionts which contribute to development of diseases by manipulating host responses (21-23). In the gut, these pathobionts are known to enhance the virulence of specific pathogens (24, 25). In the vagina, the interplay of commensals, pathogens, and pathobionts with the host is not well understood. A unique case of microbial synergism between $T$. vaginalis and its bacterial endosymbiont Mycoplasma hominis was described previously (26). In sensu stricto, microbial synergism has been redefined as a phenotype induced by the combination of $T$. vaginalis and $M$. hominis that is greater than that represented by the sum of the effects of the individual microorganisms (27). Here, we propose to investigate the possible effects that cooperative interactions between $T$. vaginalis and CST-IV bacteria might have on enhancing disease, particularly that affecting the integrity of the human cervicovaginal mucosal barrier.

The mucosal epithelia act as a natural physical barrier against the invasion of microorganisms. Selective regulation of the tightness of this intercellular space (i.e., paracellular permeability [PCP]) is necessary for the normal function of the mucosa in terms of secretion, absorption, and immune homeostasis (28). This is achieved by controlling the composition and function of the tight junctions (TJs) of the epithelial layer. It is well known that pathogenic microorganisms and mucosal inflammation can affect the integrity of the epithelial barrier by dysregulating TJs (29). With regard to the cervicovaginal mucosa, a compromised epithelial barrier promotes cervical remodeling, which is an initiating step toward preterm birth (30). A link between these events and the composition of the vaginal microbiota has been claimed, and the CST-IV bacterium G. vaginalis, in particular, has been associated with this process $(10,15,17,31)$. Protective lactobacilli, on the other hand, are known to promote cervical health by mitigating effects of proinflammatory molecules and counteracting $G$. vaginalisinduced disruption of the cervicovaginal barrier (32).

As CST-IV bacteria and T. vaginalis often coexist in the vagina, this study aimed to investigate effects of the interplay of these microorganisms on the regulation of epithelial paracellular permeability (PCP) using a polymicrobial infection model of human ectocervical cells (hECs). Here, we evaluated whether T. vaginalis and CST-IV bacteria act cooperatively in host PCP and investigated possible mechanisms used by these microorganisms to disturb the integrity of the epithelium. Our findings highlight the importance of understanding the interactions of this vaginal pathogen with the microbiota and their interplay with host responses.

\section{RESULTS}

T. vaginalis increases the paracellular permeability of a monolayer of human ectocervical cells independently of cytotoxicity effects. Virulence traits of $T$. vaginalis, such as cytoadherence and cytotoxicity, vary among strains and clinical isolates 

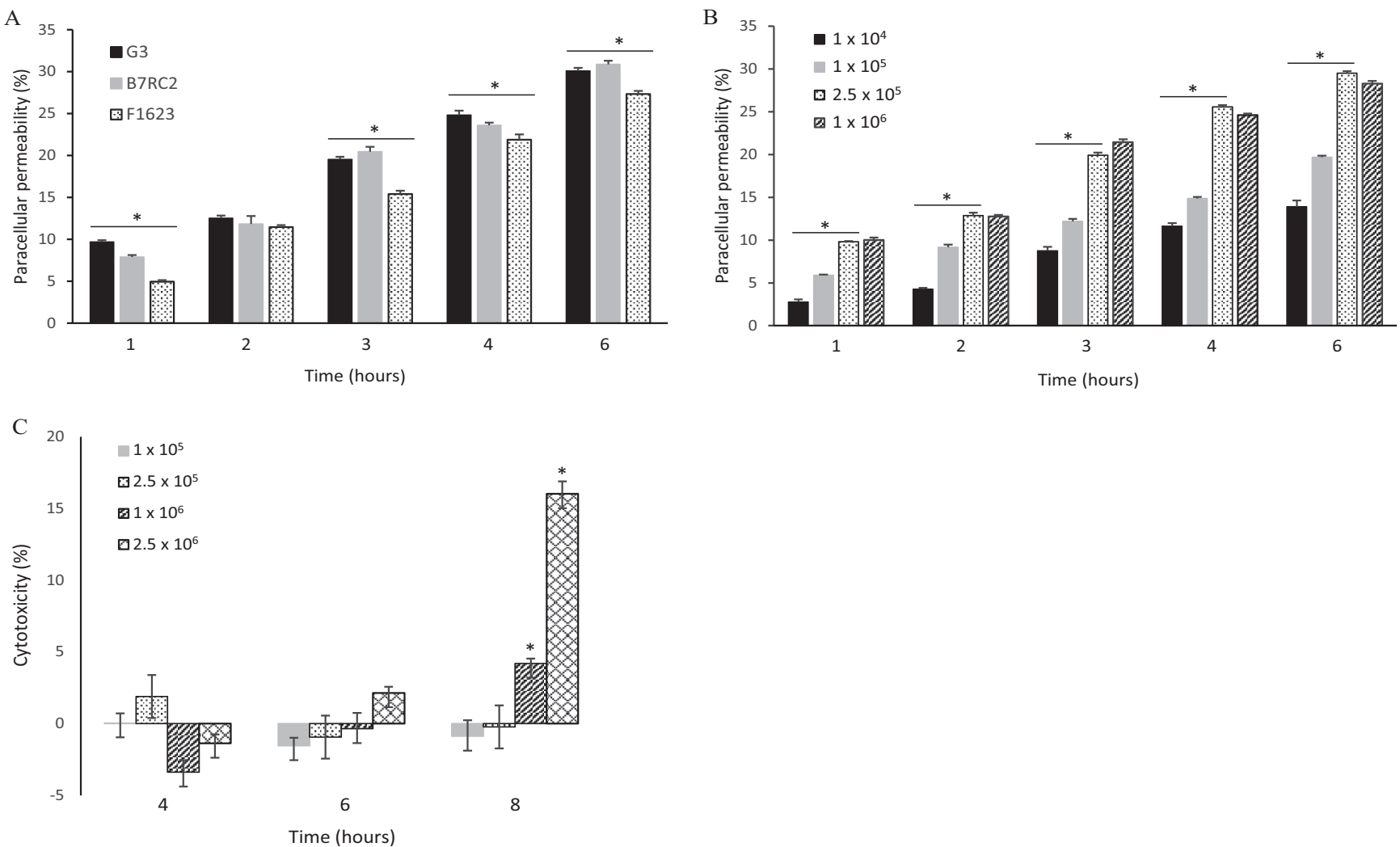

FIG $1 T$. vaginalis induces paracellular permeability of a monolayer of human ectocervical cells independently of cytotoxicity effects. (A) Paracellular permeability was assayed for three strains of $T$. vaginalis (G3, B7RC2, and F1623) in a time course experiment. (B) Paracellular permeability was assayed for T. vaginalis strain G3 at increasing concentrations (cells per milliliter, as indicated) and in a time course experiment. (C) Cytotoxicity was assayed for T. vaginalis strain G3 at increasing concentrations (cells per milliliter, as indicated) and in a time course experiment. Statistical significance is represented by an asterisk $\left({ }^{*}\right)$ for $P$ values of $>0.0001$.

(33). To evaluate whether T. vaginalis can alter the paracellular permeability (PCP) of hECs, the following three strains of $T$. vaginalis with increasing levels of host cytoadherence were selected for experimentation: G3, F1623, and B7RC2. These strains display different levels of adhesion to host cells, with B7RC2 being approximately 6-fold more adherent than G3, as measured by percentages of $T$. vaginalis attached to host cells (34, 35). Host cell cytolysis, on the other hand, is achieved only when $T$. vaginalis is incubated at a high cell concentration $\left(>1.5 \times 10^{6}\right.$ parasites $\left./ \mathrm{ml}\right)$ and after $8 \mathrm{~h}$ of coincubation with hECs $(33,36)$. Both $\mathrm{G} 3$ and B7RC2 displayed very low levels of cytotoxicity to hECs among $26 T$. vaginalis strains examined (33).

To measure PcP, a method that quantifies the diffusion of the fluorescent tracer fluorescein isothiocyanate (FITC)-dextran through a monolayer of hECs grown on ThinCell inserts was employed. To rule out the possibility that cytotoxicity might account for the alterations of PcP, cytolysis of hECs was measured by lactate dehydrogenase (LDH) release under the experimental conditions of the PcP assay (Fig. 1). It was found that all three strains were capable of increasing PcP of hECs in a time-dependent manner (Fig. 1A). The levels of PCP were not different between G3 and B7RC2, which were the strains with the lowest and highest levels of cytoadherence, reaching $a$ maximum of $\sim 30 \%$. PcP was lower for F1623 than for the other two strains at all time points. In addition, we found that the level of PcP was dependent on the concentration of $T$. vaginalis $\mathrm{G} 3$ but that it was already saturated at $2.5 \times 10^{5}$ cells $/ \mathrm{ml}$ (Fig. 1B). As expected, $T$. vaginalis $\mathrm{G} 3$ did not produce detectable levels of released LDH from hECs above the background under the conditions of the PCP assay (i.e., parasite concentration and incubation time) (Fig. 1C). A significant level of cytotoxicity was observed only at the final time point of $8 \mathrm{~h}$ for the two highest parasite concentrations $(P>0.0001)$. 

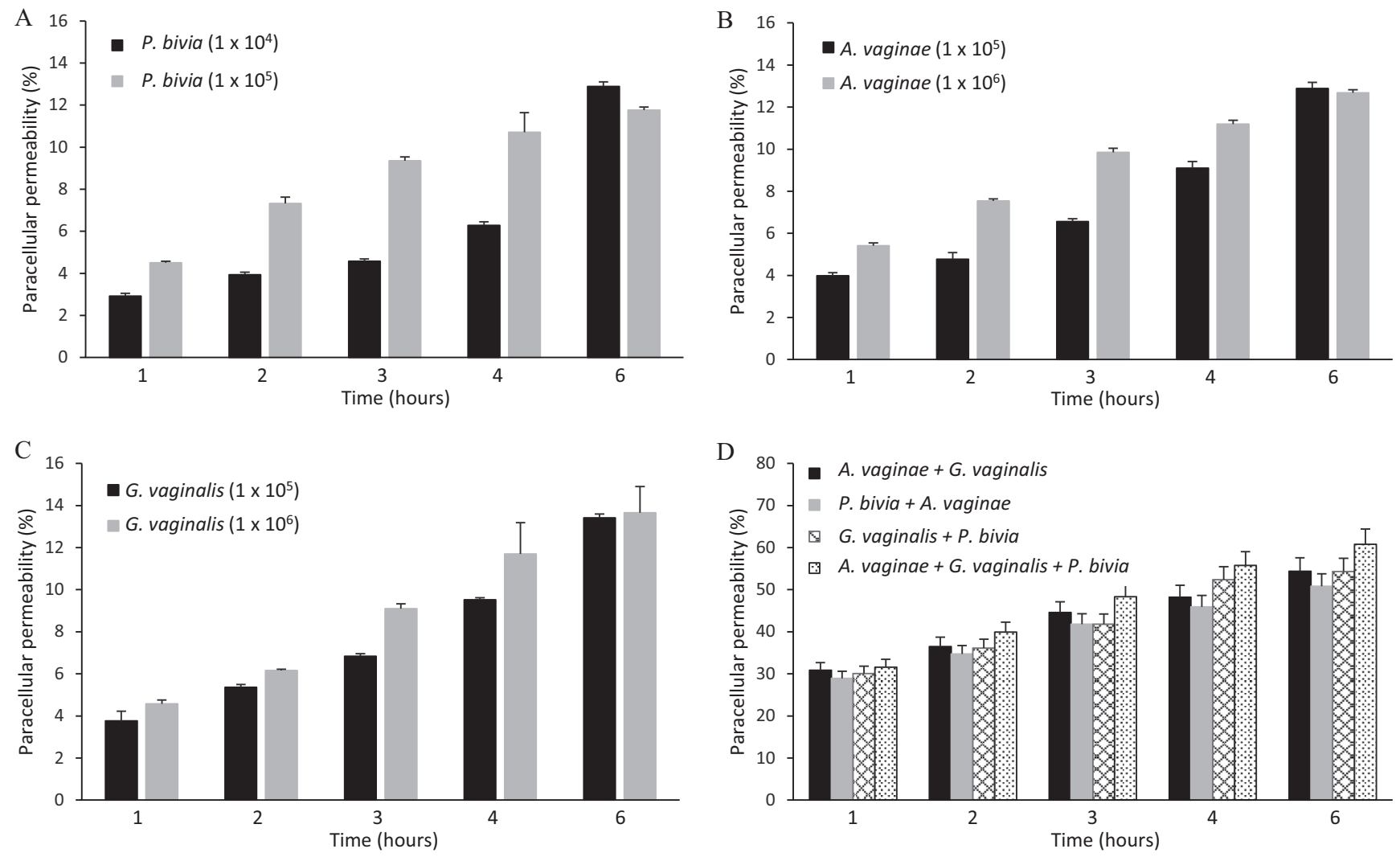

FIG 2 CST-IV bacteria induce paracellular permeability of a monolayer of human ectocervical cells. (A to C) Paracellular permeability was assayed for $P$. bivia, A. vaginae, and G. vaginalis, respectively, at two specified concentrations (cells per milliliter, as indicated), in a time course experiment. (D) Paracellular permeability was assayed for the specified combinations of $P$. bivia $\left(1 \times 10^{4}\right.$ cells $\left./ \mathrm{ml}\right)$, G. vaginalis $\left(1 \times 10^{5} \mathrm{cells} / \mathrm{ml}\right)$ and $A$. vaginae $\left(1 \times 10^{5}\right.$ cells $\left./ \mathrm{ml}\right)$ in a time course experiment.

Therefore, it was concluded that (i) relatively low numbers of $T$. vaginalis cells are capable of increasing PcP of hECs in a time-dependent manner; (ii) PcP does not correlate with the cytoadherence level of the strains; and (iii) alteration of PcP is independent of the cytotoxicity effects. The genome strain G3 was then used in the subsequent experiments.

CST-IV bacteria increase the paracellular permeability of a monolayer of human ectocervical cells. The same experimental approach as that described above was employed to evaluate if CST-IV bacteria were capable of promoting the paracellular (PcP) permeability of a hEC monolayer. The three bacterial species $G$. vaginalis, $A$. vaginae, and $P$. bivia of the vaginal community type CST-IV (2) were chosen because these are apparently associated to $T$. vaginalis infection (3) and are often the most common species of this community type $(2,37)$. Concentrations of $10^{4}$ to $10^{6}$ bacte$\mathrm{ria} / \mathrm{ml}$ were chosen on the basis of the relative levels of representation of these bacteria in this consortium $(2,38)$. All three bacterial species were capable of increasing the level of PcP in a time- and dose-dependent manner (Fig. 2). The dose-dependent response was less pronounced for G. vaginalis than for A. vaginae or P. bivia, but, at the end of $6 \mathrm{~h}$ of incubation, similar (12\% to 15\%) levels of PcP were achieved for all three bacterial species (Fig. 2A to C). Since these bacteria are found as a consortium in the vagina, the phenotypic effects of two or all three bacterial species combined were examined next. Cumulative effects on PcP were observed when bacteria were combined, without any obvious differences between the combination of any two species and the combination of all three bacterial species together (Fig. 2D). Comparing any individual bacterium to any combination of two or all bacterial species together, this cumulative effect was highly statistically significant $(P>0.0001)$, with saturation reached at $4 \mathrm{~h}$ of incubation when PcP was increased from levels of $\sim 10 \%$ to $12 \%$ to levels of $\sim 50 \%$. 

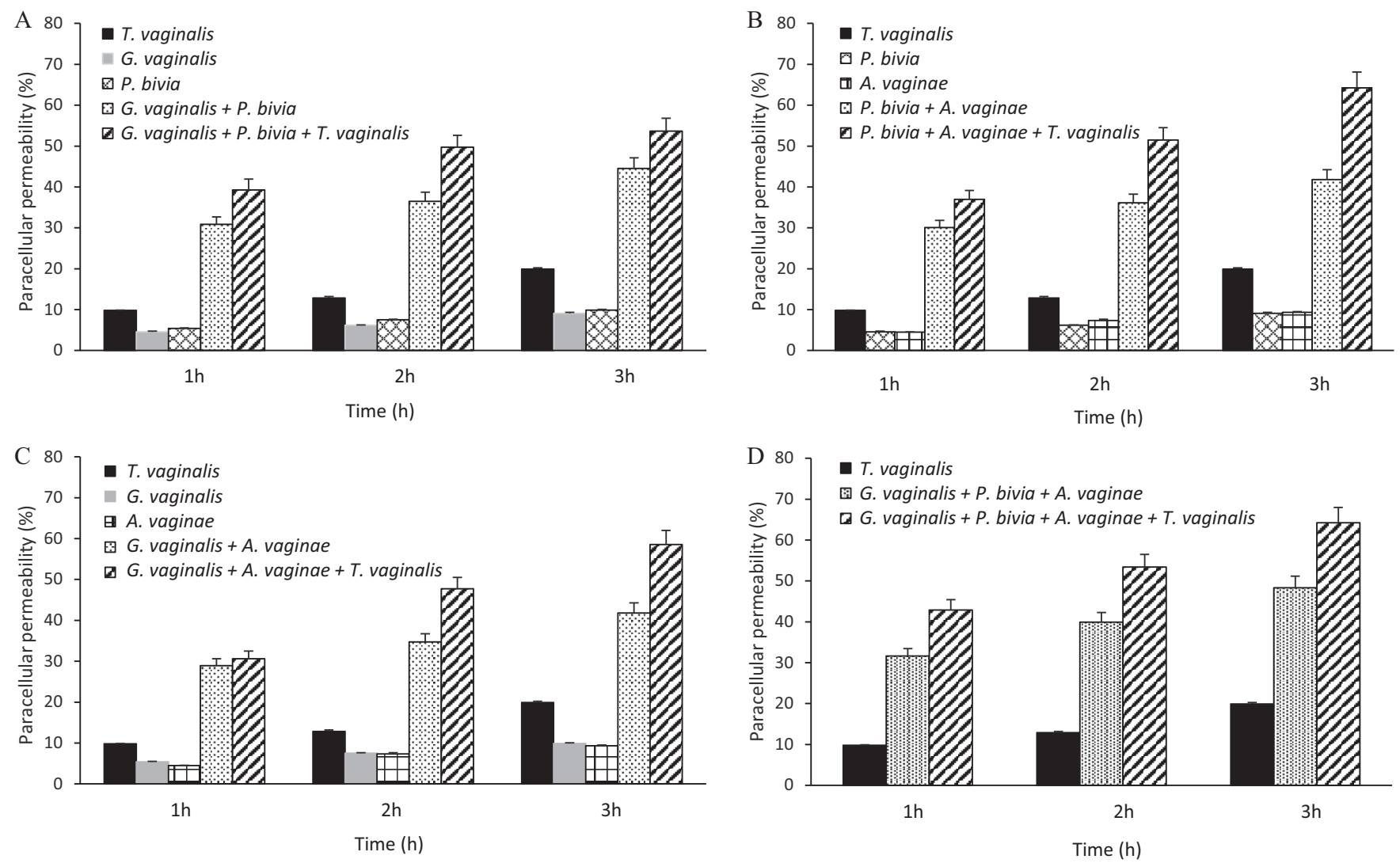

FIG 3 Paracellular permeability of a monolayer of human ectocervical cells is enhanced synergistically by the CST-IV bacteria $G$. vaginalis ( $1 \times 10^{5}$ cells/ml), $P$. bivia $\left(1 \times 10^{4} \mathrm{cells} / \mathrm{ml}\right)$, and $A$. vaginae $\left(1 \times 10^{5}\right.$ cells $\left./ \mathrm{ml}\right)$ and protozoan $T$. vaginalis strain $\mathrm{G} 3\left(2.5 \times 10^{5}\right.$ cells $\left./ \mathrm{ml}\right)$. The time course experiments were performed with each bacterium as follows: (A) G. vaginalis and/or P. bivia; (B) P. bivia and/or A. vaginae; (C) A. vaginae and/or G. vaginalis; (D) all three bacterial species together. The combined bacterial species were assayed with and without $T$. vaginalis. The differences between the results obtained with the combinations of any two or all three bacterial species and those obtained with each alone were statistically significant at all time points $(P>0.0001)$. The cumulative effects of $T$. vaginalis in combination with any two or all three bacterial species were also statistically significant at the $\mathrm{h} 2$ and $\mathrm{h} 3$ time points $(P>0.0001)$.

Paracellular permeability of a monolayer of human ectocervical cells is increased by CST-IV bacteria and $T$. vaginalis cooperatively. As described above, $T$. vaginalis promotes paracellular permeability (PcP) of a host cell monolayer to a greater extent (Fig. 1A and B) than the individual species of CST-IV bacteria (Fig. 2A to 2C) by at least 2-fold. However, it was noticeable that combining the different bacteria had a significant cumulative effect on this phenotype (Fig. 2D). The contribution of individual CST-IV bacterial species and T. vaginalis to the PcP of hECs was therefore further investigated to evaluate if cooperative interactions between bacteria or between bacteria and protozoa might enhance this phenotype.

Accordingly, PcP assays were conducted for T. vaginalis, the individual bacterial species, and a combination of two or all three bacterial species with and without the parasite (Fig. 3). Since the cumulative effect of CST-IV bacteria was apparently saturated at 4 to $6 \mathrm{~h}$ of incubation (Fig. 2D), analyses were conducted within the first $3 \mathrm{~h}$. As previously observed, $T$. vaginalis induced at least two times more PcP than the individual bacterial species. However, any combination of bacteria (any two or all three bacterial species) was able to alter PcP of hECs to a level higher than that seen with $T$. vaginalis alone. This alteration was synergistic, as defined sensu stricto previously (27), as shown by the fact that any two bacterial species (Fig. $3 \mathrm{~A}$ to $\mathrm{C}$ ) or all bacterial species together (Fig. 3D) induced PcP at a level at least 3.5-fold greater than the sum of results measured with the individual bacterial species ( $30 \%$ to $40 \%$ versus $<10 \%$, respectively). In addition, the PCP induced by the parasite in the presence of one, two, or all three bacterial species was apparently cumulative (Fig. 3). 

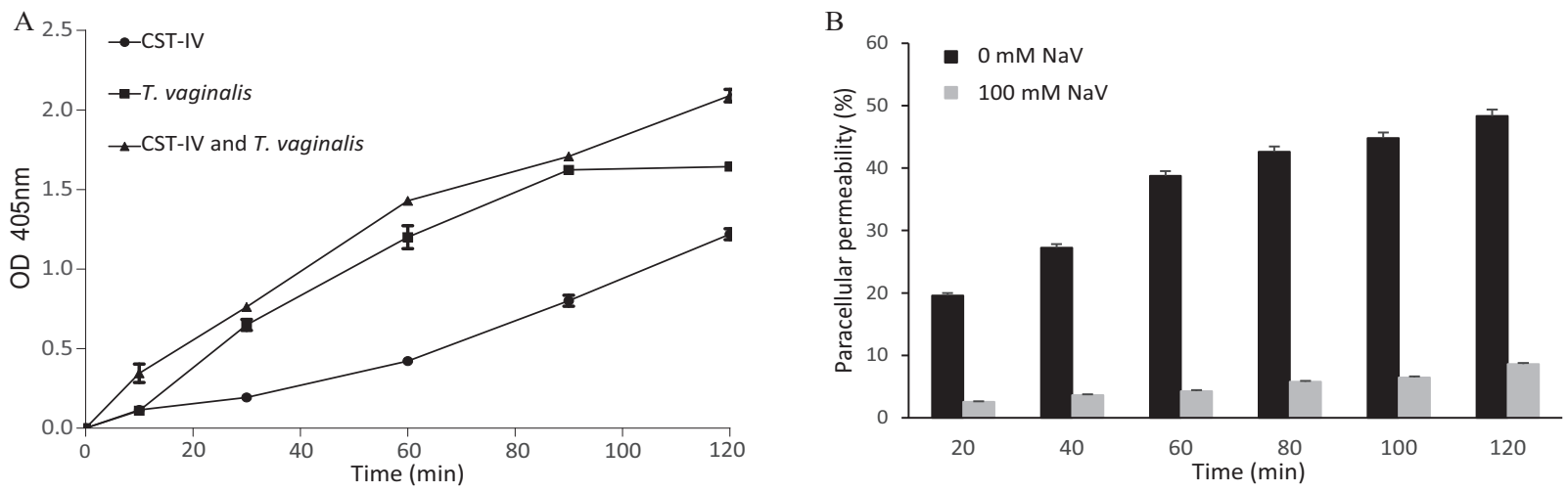

FIG 4 The paracellular permeability of a monolayer of human ectocervical cells, as induced by CST-IV bacteria and T. vaginalis strain G3, is accompanied by an increase of phosphatase activity, and phosphatase inhibition protects the integrity of this epithelial monolayer. The concentrations of $T$. vaginalis and the CST-IV bacteria (G. vaginalis, A. vaginae, and P. bivia) were the same as those shown in Fig. 3. (A) The cell monolayer was incubated with the CST-IV bacterial species or with $T$. vaginalis or with the two together, and phosphatase activity was quantified by colorimetric detection of $p$-nitrophenyl phosphate hydrolysis. Values from the cell monolayer alone, in the absence of bacteria and protozoan, were used as a blank. The differences between the CST-IV samples and the other two samples were statistically significant from 30 min onwards $(P>0.0001)$. OD $405 \mathrm{~nm}$, optical density at $405 \mathrm{~nm}$. (B) Paracellular permeability of the cell monolayer, as induced by $T$. vaginalis in combination with the CST-IV bacteria, was assayed with 0 and $100 \mathrm{mM}$ concentrations of the phosphatase inhibitor sodium orthovanadate (NaV). The differences between 0 and $100 \mathrm{mM} \mathrm{NaV}$ were statistically significant for all time points $(P>0.0001)$.

Paracellular permeability and phosphatase activity. Mucosal pathogens often alter the barrier function of the host epithelium by inducing paracellular permeability (PCP) via dysregulation of TJs. One of the key mechanisms for controlling the integrity and function of TJs is dephosphorylation of their major protein components (29, 39-42). It is possible that phosphatases could be responsible for the increase in the level of PCP associated with T. vaginalis and CST-IV bacteria that was observed as described above. The level of phosphatase activity during colonization of hECs by these microorganisms and the extent to which inhibiting phosphatase activity could prevent or restore the epithelial barrier function were therefore examined next.

An assay method widely used for phosphatase activity is the colorimetric and quantitative determination of para-nitrophenol following removal of inorganic phosphate from para-nitrophenyl phosphate (pNPP). This assay was used to detect enhanced phosphatase activity when hECs were incubated with T. vaginalis and/or CST-IV bacteria. The concentrations of protozoal and bacterial cells used were the same as in the previous PCP assays. A pronounced time-dependent enhancement of phosphatase activity, detected as early as $15 \mathrm{~min}$, was observed when hECs were incubated with the microorganisms (Fig. 4A). T. vaginalis was a better inducer of phosphatase activity than CST-IV bacteria, with a slight cumulative effect when protozoa and bacteria were present together.

If phosphatase activity is implicated in the induction of PCP, then inhibiting phosphatase activity might alleviate the effects that these microorganisms have on PcP of the hECs. To demonstrate that, the general phosphatase inhibitor sodium orthovanadate (NaV) was used. It was found that the inhibitor was capable of reducing the cooperative effects that CST-IV bacteria and T. vaginalis have on the PCP of the hEC monolayer (Fig. 4B). This reduction in PCP was immediate and very significant at up to 40-fold compared to the control $(P>0.0001)$. However, even with the inhibitor, the hEC monolayer was not completely tight when in the presence of the microorganisms. In fact, tightness of the cell monolayer was increasingly lost from 20 to 120 min of incubation. It may be that phosphatases are not being completely inhibited by the $\mathrm{NaV}$ - other phosphase-independent effector mechanisms may play a role in PcPand/or that accumulation of phosphatases can overcome $\mathrm{NaV}$ inhibition over time.

Expression of tight junction proteins and proinflammatory cytokines. The findings described above indicate that TJ proteins may be targeted by the enhanced levels of phosphatases when hECs are colonized by $T$. vaginalis and/or CST-IV bacteria. In 

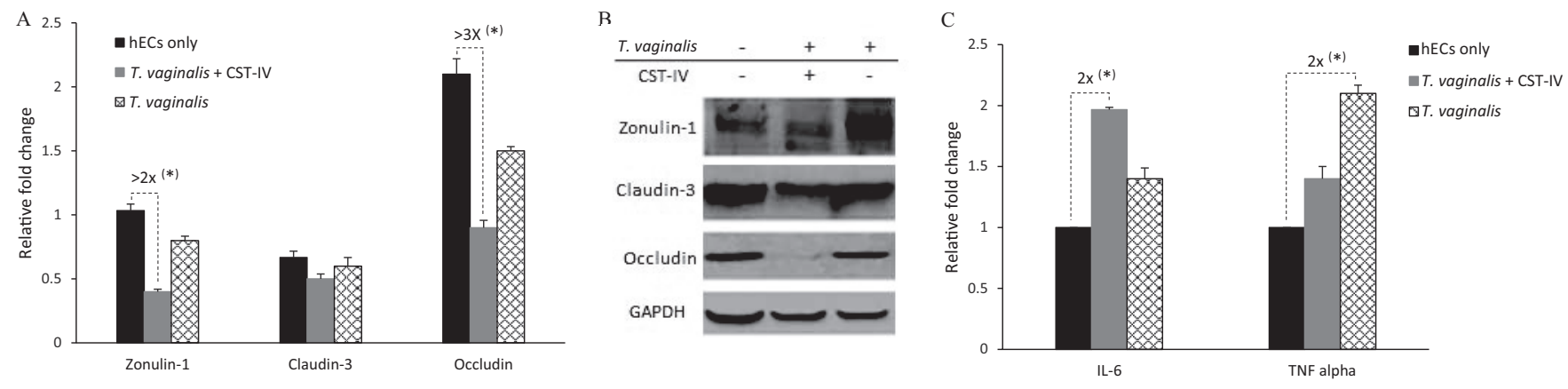

FIG 5 T. vaginalis and CST-IV bacteria affect expression of tight junction genes and the cytokines IL- 6 and TNF- $\alpha$ in human ectocervical cells. Relative gene expression levels were compared between conditions where host cells were not exposed to the microorganisms (hECs only) and conditions where host cells were exposed to $T$. vaginalis alone or to $T$. vaginalis in combination with the CST-IV bacteria. The concentrations of $T$. vaginalis and the CST-IV bacteria (G. vaginalis, A. vaginae, and P. bivia) were the same as those shown in Fig. 3. (A) Transcriptional regulation of zonulin-1, claudin-3, and occludin detected by RT-qPCR. (B) Western blots showing relative protein abundances of zonulin-1, claudin-3, and occludin compared to GAPDH. (C) Transcriptional regulation of IL- 6 and TNF- $\alpha$ detected by RT-qPCR. Dashed connectors indicate the highest differences between samples with respect to effects on the expression of these genes, indicating relative fold differences with $P>0.0001\left({ }^{*}\right)$.

addition, disruption of the TJ barrier function may be caused by changes in expression of $\mathrm{TJ}$ genes, at transcriptional and posttranscriptional levels, as well as by proinflammatory responses (29). Zonulin-1, claudin-3, and occludin are major structural components of the TJ and are highly involved in its integrity (29). hECs are known to produce proinflammatory molecules in response to $T$. vaginalis and CST-IV bacterial species (43).

First, the expression levels of zonulin-1, claudin-3, and occludin were compared for $\mathrm{hEC}$ that were exposed or not exposed to T. vaginalis with and without CST-IV bacteria (Fig. 5A and B). To reveal changes at the transcriptional and posttranscriptional levels, these assessments were done by reverse transcription-quantitative PCR (RT-qPCR) and Western blotting, respectively. The products of the housekeeping GAPDH (glyceraldehyde-3-phosphate dehydrogenase) gene, mRNA and protein, were used as a normalizer for the RT-qPCR and as a loading control for the Western blotting, respectively. The zonulin-1 and occludin genes, but not the claudin-3 gene, were transcriptionally downregulated in the presence of the microorganisms (Fig. 5A). Downregulation was statistically significant and more pronounced with the combination of $T$. vaginalis and CST-IV bacteria than with $T$. vaginalis alone, by 2 -fold to 3 -fold $(P>0.0001)$. The Western blotting results showed that, while there were no apparent alterations in the abundances of the zonulin-1 and occludin proteins, occludin was barely detectable in the hECs when both the protozoa and bacteria were present (Fig. 5B).

Second, the levels of expression of cytokines interleukin-6 (IL-6) and tumor necrosis factor alpha (TNF- $\alpha$ ) were evaluated by RT-qPCR. These cytokines regulate assembly of TJs, and changes in their abundance are associated with mucosal inflammation and infection (29). Statistically significant upregulation of both cytokines was detected when the hECs were in the presence of the microorganisms, by up to 2-fold $(P>0.0001)$ (Fig. 5C). However, no cumulative effect of T. vaginalis and CST-IV bacteria on the transcription upregulation of these cytokines was evident (Fig. 5C).

\section{DISCUSSION}

The integrity of the human cervicovaginal epithelium is of importance because it prevents pathogen invasion and toxin dissemination to the underlying tissue. Decreased barrier function facilitates the passage of HIV (44) and promotes cervical remodeling, which is an initiating step toward preterm birth $(10,17,30)$. Trichomoniasis and bacterial vaginosis are both associated with increased risk of HIV transmission, premature rupture of membranes, and preterm birth (5-14). The T. vaginalis parasite is accompanied by species of CST-IV bacteria that are coincidently found in bacterial vaginosis $(3,4)$. Therefore, we were particularly interested in the cooperative effects 
that these microorganisms could have on the induction of paracellular permeability (PcP) of human ectocervical cells (hECs).

We have shown here that $T$. vaginalis alone at low cell concentrations, where cytotoxicity is negligible, is capable of inducing PcP of hECs. T. vaginalis has been shown to affect the integrity of monolayers of other epithelial cell types in a straindependent manner $(44,45)$. However, in contrast to a previous report $(45)$, our findings do not support the idea of a correlation between levels of PcP and cytoadherence of the $T$. vaginalis strains. We have shown that CST-IV bacteria are also capable of inducing $\mathrm{PcP}$, displaying synergism between any two of the three main species found to coexist with $T$. vaginalis infections, namely, G. vaginalis, A. vaginae, and P. bivia. Together, cooperative interactions between protozoan and bacteria result in significant cumulative effects on PcP of the hEC monolayer. Under conditions of induction by these microorganisms, PcP is accompanied by a marked enhancement of phosphatase activity. Noticeably, the inhibition of phosphatase activity prevented PcP almost completely. Increased phosphatase activity at the mucosal interface is highly suggestive of barrier dysfunction (29, 39-42).

Although the involvement of other mechanisms cannot be ruled out, our observations suggest that alteration of the phosphorylation status of the TJ proteins on the cervicovaginal mucosa is potentially one of the major pathogenic mechanisms linked to the disruption of this physical barrier in the vagina induced by these microorganisms cooperatively. A parallel exists with Entamoeba histolytica. This gut protozoan can alter $\mathrm{PcP}$ of the intestinal epithelial barrier by disturbing the TJs by degradation of and/or changes in the phosphorylation status of its components $(46,47)$, possibly using membrane-associated and secreted tyrosine phosphatases $(48,49)$. Various bacterial gut pathogens can also alter TJs by using specific toxins or by interfering with the expression of the TJ components and/or assembly of the complex (29).

Our study did not reveal the molecules involved in the physical disruption of the hEC barrier by these vaginal microorganisms, but the data possibly indicate that enhancement of phosphatase activity is among the major underlying mechanisms that lead to TJ dysregulation of the host cervicovaginal epithelium. Disruption of this barrier has been attributed to $G$. vaginalis $(10,17,32)$, but the mechanisms are not yet understood and no phosphatases have been claimed to be involved. On the other hand, phosphatase activity has been found in various cellular compartments of $T$. vaginalis, including on its surface and in secreted fractions (50); those findings have been recently supported by proteomics data $(51,52)$. In fact, the $T$. vaginalis genome has experienced a dramatic expansion of phosphatase gene families displaying the largest repertoire among protozoans $(53,54)$. Therefore, phosphatases should play key roles in various pathophysiological aspects of this parasite and might be implicated in the modulation of the hEC PcP.

In addition to the phosphatase activity, we have shown that occludin is downregulated in hECs when these microorganisms were present. Occludin, a major component of the TJ complex, is phosphorylated at different sites and its cytolocalization responds to the phosphorylation status of the protein $(29,39-42)$. The downregulation of occludin expression and possibly of dephosphorylation due to enhanced levels of phosphatase activity could lead to poor assembly of the TJ complex. The loss of the regulatory function of occludin can explain the PcP alterations of the hEC monolayer as induced by T. vaginalis and CST-IV bacteria. Moreover, these microorganisms induce expression of the proinflammatory molecules IL- 6 and TNF- $\alpha$, which are known to negatively affect the epithelial barrier function (29). Together, the changes that occur following the polymicrobial infection of hECs by T. vaginalis and CST-IV bacteria are aligned to other disease conditions of the mucosa, such as colitis and inflammatory bowel diseases, which are also characterized by disruption of the epithelial barrier (29).

Historically, the interaction of $T$. vaginalis with the vaginal microbiota has received little consideration from parasitologists, microbiologists, and clinicians alike. Our group has previously shown that protective lactobacilli of the vagina can prevent cytoadhesion of $T$. vaginalis (35) by displaying an aggregation-promoting factor on the bacterial 
surface (55). On the other hand, bacteria often associated with $T$. vaginalis infection enhance proinflammatory responses to Trichomonas-specific antigens (43). This study demonstrated the importance of understanding the interactions between the protozoal pathogen $T$. vaginalis and the associated bacteria. Cooperative interactions between these microorganisms lead to disruption of the cervicovaginal epithelial barrier, which is likely capable of amplifying the disease.

\section{MATERIALS AND METHODS}

Cell culture. Human ectocervical cells (hECs; ATCC CRL-2614) were cultured in serum-free keratinocyte media (K-SFM; Life Technologies) at $37^{\circ} \mathrm{C}$ under a $5 \% \mathrm{CO}_{2}$ atmosphere. Gardnerella vaginalis, Prevotella bivia, and Atopobium vaginae (NZRM 810, NZRM 4359, and NZRM 4379, respectively) were cultured in NYC III media at $37^{\circ} \mathrm{C}$ under microaerophilic conditions (i.e., using media filled to the top of the tubes and with no agitation). Trichomonas vaginalis strains G3, F1623, and B7RC2 were cultured in TYM medium (56) supplemented with $10 \%$ horse serum, $10 \mathrm{U} / \mathrm{ml}$ penicillin, and $10 \mu \mathrm{g} / \mathrm{ml}$ streptomycin (Invitrogen) under microaerophilic conditions at $37^{\circ} \mathrm{C}$. Antibiotics were washed off cultures, which were maintained without antibiotics for at least $48 \mathrm{~h}$ before being used in the experiments. Microbial cells with viability of $>90 \%$ were counted from overnight liquid cultures, as described previously, and freshly used in the experiments on the same day (35).

Paracellular permeability. hECs were grown on ThinCert inserts (Greiner Bio-One) (pore size, of $0.4 \mu \mathrm{m}$ ) in 24-well plates to a confluent monolayer. K-SFM was replaced by 250 and $500 \mu \mathrm{l}$ of Hanks' balanced salt solution (Sigma-Aldrich) in the top and bottom compartments, respectively. The top compartment received $10 \mu \mathrm{g} / \mathrm{ml}$ of fluorescein isothiocyanate-dextran (FITC-dextran) (Sigma-Aldrich) $(70 \mathrm{kDa})$. T. vaginalis and/or the bacteria were inoculated into the top compartment at the concentrations indicated for each experiment. The negative control contained the cell monolayer without the microorganisms. The positive control (100\% FITC-dextran diffusion) did not contain a cell monolayer or microorganisms. At the specified time points, $10 \mu \mathrm{l}$ was removed from the lower chamber of the wells and diluted into $90 \mu \mathrm{l}$ water in a 96-well plate and the fluorescence was read at an excitation wavelength of $492 \mathrm{~nm}$ and an emission wavelength of $518 \mathrm{~nm}$ using a plate reader (EnSpire; PerkinElmer). Fluorescence data were subtracted from the negative-control data and compared to values determined for the $100 \%$ control. The PCP assay was performed in the presence of $100 \mu \mathrm{M}$ sodium orthovanadate (Sigma-Aldrich) following the same procedure. Experiments were done as three independent replicates.

Cytotoxicity assay. hECs were grown on a 96-well plate to form a confluent monolayer. K-SFM was replaced by $100 \mu \mathrm{l}$ of $T$. vaginalis, which was resuspended in the same media and at the concentrations specified for the experiments. As controls, hECs had media replaced without parasites. After replacement of the media, the plates were incubated at $37^{\circ} \mathrm{C}$ under a $5 \% \mathrm{CO}_{2}$ atmosphere for up to $8 \mathrm{~h}$. The cytotoxicity assay, based on release of lactate dehydrogenase (LDH), was performed following the CytoTox-One homogeneous membrane integrity assay protocol (Promega). Briefly, after incubations, plates were centrifuged at 3,000 $\times g$ for $2 \mathrm{~min}$. A 50- $\mu$ l volume of the supernatant was collected and mixed with an equal volume of CytoTox-One substrate following incubation for $20 \mathrm{~min}$. The supernatant of the control (no parasites) served as the background of LDH release. The maximum LDH release control was obtained from cells without parasites, lysed deliberately as recommended by the manufacturer (Promega). The background value was subtracted from all values determined for the experimental wells, and LDH release was quantified by analysis of fluorescence using an EnSpire plate reader, as recommended. A percentage of cytotoxicity corresponding to the level of parasite-induced cytotoxicity compared to the maximum LDH release was obtained. Assays were performed in triplicate.

Phosphatase activity. This assay was done with monolayers of hECs in 96-well plates. K-SFM was replaced by $0.1 \mathrm{ml}$ of phosphate-saline buffer containing T. vaginalis and/or bacteria (with the cell concentrations indicated for the experiments) in the presence of $10 \mathrm{mM} \mathrm{p}$-nitrophenyl phosphate (pNpp; Sigma-Aldrich). Incubation proceeded at $37^{\circ} \mathrm{C}$ for up to $2 \mathrm{~h}$. Reactions were stopped by the addition of $0.1 \mathrm{ml}$ of $1 \mathrm{M} \mathrm{NaOH}$. Absorbance was read at $405 \mathrm{~nm}$, and values were subtracted from those determined for the negative control, which consisted of hECs treated under the same conditions but without the microorganisms.

RNA isolation, reverse transcription, and quantitative PCR (RT-qPCR). Coincubations of hECs and microorganisms replicated the conditions described above for the paracellular permeability assays, and RNA was obtained at $2 \mathrm{~h}$ postincubation. Total RNA was extracted using an RNeasy kit following the instructions of the manufacturer (Qiagen). A 1- $\mu$ g volume of total RNA was reverse transcribed into CDNA with oligo(dT) primer (SuperScript III RT; Invitrogen). Real-time PCR was performed in triplicate with $20 \mathrm{ng}$ of CDNA, PowerUP SYBR green master mix (Thermo Fisher), and a $200 \mathrm{nM}$ concentration of each forward (F) primer and reverse (R) primer, targeting the following human genes: for the occludin gene, $F$ primer CACATCACAATAATGAGCATAGACAGG and $\mathrm{R}$ primer CACATCACAATAATGAGCATAGACAGG; for the claudin-3 gene, F primer GGCGGTAGCAGGTGGAGTC and R primer CTTGGTAGGCATCGTAGTAGTTGG; for the zonulin-1 gene, $\mathrm{F}$ primer CAAGATAGTTTGGCAGCAAGAGATG and R primer ATCAGGGACATTCAATA GCGTAGCC; for the IL- 6 gene, F primer TGATGGATGCTTCCAAACTG and R primer GAGCATTGGAAGTTG GGATA; for the TNF- $\alpha$ gene, F primer ACTGAACTTCAAGGTGATTG and R primer GCTTGGTGGTTTGCTAC GAC; and for the GAPDH gene, F primer GTATTGGGCGGCTGGTCACC and R primer CGCTCCTGGAAGAT GGTGATGG. The threshold cycle $\left(C_{T}\right)$ method was applied for relative gene expression analysis, comparing levels of gene expression from $\mathrm{hECs}$ in the presence versus absence of the microorganisms. Expression data were normalized and analyzed using the SDS 2.3 and RQ Manager 1.2 applications 
(Applied Biosystems). Subsequent statistical analyses were then carried out using the Relative Expression Software Tool (57).

Immunoblotting. Total cell lysates of hECs were prepared with a Triton X-100 lysis protocol, as previously described (58). The protein concentration was determined by the Bradford assay (Bio-Rad). A total of $20 \mu \mathrm{g}$ of protein was separated on a 12\% SDS-PAGE gel. After electrophoresis, proteins were blotted to polyvinylidene difluoride (PVDF) membranes and incubated with blocking buffer (5\% bovine serum albumin [BSA]-Tris-buffered saline-0.1\% Tween 20) for $1 \mathrm{~h}$ at room temperature. This was followed by incubation with a 1:1,000 dilution of the antibodies overnight at $4^{\circ} \mathrm{C}$. Antibodies were used against the following human proteins: GAPDH, zonulin-1, and claudin-3 (Life Technologies) and occludin (Abcam). Membranes were washed three times with the buffer described above (without BSA) before incubation with horseradish peroxidase-conjugated secondary antibodies (Life Technologies), diluted 1:5,000 in the blocking buffer, for $1 \mathrm{~h}$ at room temperature. After repeating washes, the immunoreactivity signal was detected from the blots using ECL (Thermo Fisher) and an Amersham 600 imager.

Statistical analysis. Statistical significance was determined using data from experimental replicates, applying one-way and two-way analysis of variance (ANOVA) and Turkey's multiple-comparison test.

\section{ACKNOWLEDGMENTS}

All of us contributed to and reviewed the manuscript. None of us have a competing financial interest or conflicting interests in any aspect of the research reported here.

We are grateful to the research funders, specifically, the Health Research Council of New Zealand (HRC11/314), the Maurice \& Phyllis Paykel Trust, and the Faculty of Science Research Development Fund at the University of New Zealand (all funding provided to A.S.-B.). The funders had no role in study design, data collection and interpretation, or the decision to submit the work for publication.

\section{REFERENCES}

1. World Health Organization. 2015. Sexually transmitted infection (STIs). World Health Organization, Geneva, Switzerland.

2. Ravel J, Gajer P, Abdo Z, Schneider GM, Koenig SSK, McCulle SL, Karlebach S, Gorle R, Russell J, Tacket CO, Brotman RM, Davis CC, Ault K, Peralta L, Forney LJ. 2011. Vaginal microbiome of reproductive-age women. Proc Natl Acad Sci U S A 108:4680-4687. https://doi.org/10 $.1073 /$ pnas. 1002611107 .

3. Brotman RM, Bradford L, Conrad M, Gajer P, Ault K, Peralta L, Forney LJ, Carlton JM, Abdo Z, Ravel J. 2012. Association between Trichomonas vaginalis and vaginal bacterial community composition among reproductive-age women. Sex Transm Dis 39:807-812. https://doi.org/ 10.1097/OLQ.0b013e3182631c79.

4. Rathod SD, Krupp K, Klausner JD, Arun A, Reingold AL, Madhivanan P. 2011. Bacterial vaginosis and risk for Trichomonas vaginalis infection: a longitudinal analysis. Sex Transm Dis 38:882-886. https://doi.org/10 .1097/OLQ.0b013e31821f91a1.

5. Cotch MF, Pastorek JG, Nugent RP, Hillier SL, Gibbs RS, Martin DH, Eschenbach DA, Edelman R, Carey CJ, Regan JA, Krohn MA, Klebanoff MA, Rao VA, Rhoads GG. 1997. Trichomonas vaginalis associated with low birth weight and preterm delivery. The Vaginal Infections and Prematurity Study. Sex Transm Dis 24:353-360. https://doi.org/10 .1097/00007435-199707000-00008.

6. Minkoff H, Grunebaum AN, Schwarz RH, Feldman J, Cummings $M$, Crombleholme W, Clark L, Pringle G, McCormack WM. 1984. Risk factors for prematurity and premature rupture of membranes: a prospective study of the vaginal flora in pregnancy. Am J Obstet Gynecol 150: 965-972. https://doi.org/10.1016/0002-9378(84)90392-2.

7. Witkin SS. 2015. The vaginal microbiome, vaginal anti-microbial defence mechanisms and the clinical challenge of reducing infection-related preterm birth. BJOG 122:213-238. https://doi.org/10.1111/1471-0528 .13115.

8. Tabatabaei N, Eren AM, Barreiro LB, Yotova V, Dumaine A, Allard C. 2018. Vaginal microbiome in early pregnancy and subsequent risk of spontaneous preterm birth: a case-control study. BJOG https://doi.org/10.1111/ 1471-0528.15299.

9. Nelson DB, Hanlon A, Hassan S, Britto J, Greifman-Holtzman O, Haggerty C, Fredricks DN. 2009. Preterm labor and bacterial vaginosis-associated bacteria among urban women. J Perinat Med 37:130-134. https://doi .org/10.1515/JPM.2009.026.

10. Sierra LJ, Brown AG, Barila GO, Anton L, Barnum CE, Shetye SS, Soslowsky LJ, Elovitz MA. 2018. Colonization of the cervicovaginal space with Gardnerella vaginalis leads to local inflammation and cervical remodel- ing in pregnant mice. PLoS One 13:e0191524. https://doi.org/10.1371/ journal.pone.0191524.

11. Laga M, Manoka A, Kivuvu M, Malele B, Tuliza M, Nzila N, Goeman J, Behets F, Batter V, Alary M, Heyward WL, Ryder RW, Piot P. 1993. Non-ulcerative sexually transmitted diseases as risk factors for HIV-1 transmission in women: results from a cohort study. AIDS 7:95-102. https://doi.org/10.1097/00002030-199301000-00015.

12. Kissinger P. 2015. Trichomonas vaginalis: a review of epidemiologic, clinical and treatment issues. BMC Infect Dis 15:307. https://doi.org/10 .1186/s12879-015-1055-0.

13. Martin HL, Richardson BA, Nyange PM, Lavreys L, Hillier SL, Chohan B, Mandaliya K, Ndinya-Achola JO, Bwayo J, Kreiss J. 1999. Vaginal lactobacilli, microbial flora, and risk of human immunodeficiency virus type 1 and sexually transmitted disease acquisition. J Infect Dis 180:1863-1868. https://doi.org/10.1086/315127.

14. Taha TE, Gray RH, Kumwenda NI, Hoover DR, Mtimavalye LA, Liomba GN, Chiphangwi JD, Dallabetta GA, Miotti PG. 1999. HIV infection and disturbances of vaginal flora during pregnancy. J Acquir Immune Defic Syndr Hum Retrovirol 20:52-59. https://doi.org/10.1097/00042560-199901010 -00008 .

15. Mitchell C, Marrazzo J. 2014. Bacterial vaginosis and the cervicovaginal immune response. Am J Reprod Immunol 71:555-563. https://doi.org/ 10.1111/aji.12264

16. Santos-Greatti MMV, da Silva MG, Ferreira CST, Marconi C. 2016. Cervicovaginal cytokines, sialidase activity and bacterial load in reproductiveaged women with intermediate vaginal flora. J Reprod Immunol 118: 36-41. https://doi.org/10.1016/j.jri.2016.08.005.

17. Bradley $F$, Birse $K$, Hasselrot $K$, Noël-Romas $L$, Introini $A$, Wefer $H$, Seifert M, Engstrand L, Tjernlund A, Broliden K, Burgener AD. 2018. The vaginal microbiome amplifies sex hormone-associated cyclic changes in cervicovaginal inflammation and epithelial barrier disruption. Am J Reprod Immunol 80:e12863. https://doi.org/10.1111/aji.12863.

18. Amabebe E, Anumba D. 2018. The vaginal microenvironment: the physiologic role of lactobacilli. Front Med (Lausanne) 5:181. https://doi.org/ 10.3389/fmed.2018.00181.

19. Bjornson HS. 1982. Bacterial synergy, virulence factors, and host defense mechanisms in the pathogenesis of intraabdominal infections, p 65-78. In Simmons RL (ed), Topics in intraabdominal surgical infection. Appleton-Century-Crofts, Norwalk, CT.

20. Murray JL, Connell JL, Stacy A, Turner KH, Whiteley M. 2014. Mechanisms of synergy in polymicrobial infections. J Microbiol 52:188-199. https:// doi.org/10.1007/s12275-014-4067-3. 
21. Cerf-Bensussan N, Gaboriau-Routhiau V. 2010. The immune system and the gut microbiota: friends or foes? Nat Rev Immunol 10:735-744. https://doi.org/10.1038/nri2850.

22. Hornef M. 2015. Pathogens, commensal symbionts, and pathobionts: discovery and functional effects on the host. ILAR J 56:159-162. https:// doi.org/10.1093/ilar/ilv007.

23. Zechner EL. 2017. Inflammatory disease caused by intestinal pathobionts. Curr Opin Microbiol 35:64-69. https://doi.org/10.1016/j.mib .2017.01.011.

24. Stecher B, Hardt WD. 2008. The role of microbiota in infectious disease Trends Microbiol 16:107-114. https://doi.org/10.1016/j.tim.2007.12.008.

25. Kamada N, Chen GY, Inohara N, Núñez G. 2013. Control of pathogens and pathobionts by the gut microbiota. Nat Immunol 14:685-690. https://doi.org/10.1038/ni.2608.

26. Dessì D, Margarita V, Cocco AR, Marongiu A, Fiori PL, Rappelli P. 2019. Trichomonas vaginalis and Mycoplasma hominis: new tales of two old friends. Parasitology 2019:1-6.

27. Fiori PL, Diaz N, Cocco AR, Rappelli P, Dessi D. 2013. Association of Trichomonas vaginalis with its symbiont Mycoplasma hominis synergistically upregulates the in vitro proinflammatory response of human monocytes. Sex Transm Infect 89:449-454. https://doi.org/10.1136/ sextrans-2012-051006.

28. Shen L, Weber CR, Raleigh DR, Yu D, Turner JR. 2011. Tight junction pore and leak pathways: a dynamic duo. Annu Rev Physiol 73:283-309. https://doi.org/10.1146/annurev-physiol-012110-142150.

29. Schulzke JD, Günzel D, John LJ, Fromm M. 2012. Perspectives on tight junction research. Ann N Y Acad Sci 1257:1-19. https://doi.org/10.1111/ j.1749-6632.2012.06485.x.

30. Timmons B, Akins M, Mahendroo M. 2010. Cervical remodeling during pregnancy and parturition. Trends Endocrinol Metab 21:353-361. https://doi.org/10.1016/j.tem.2010.01.011.

31. DiGiulio DB, Callahan BJ, McMurdie PJ, Costello EK, Lyell DJ, Robaczewska A, Sun CL, Goltsman DS, Wong RJ, Shaw G, Stevenson DK, Holmes SP, Relman DA. 2015. Temporal and spatial variation of the human microbiota during pregnancy. Proc Natl Acad Sci U S A 112: 11060-11065. https://doi.org/10.1073/pnas.1502875112.

32. Anton L, Sierra LJ, DeVine A, Barila G, Heiser L, Brown AG, Elovitz MA 2018. Common cervicovaginal microbial supernatants alter cervical epithelial function: mechanisms by which Lactobacillus crispatus contributes to cervical health. Front Microbiol 9:2181. https://doi.org/10.3389/ fmicb.2018.02181

33. Lustig G, Ryan CM, Secor WE, Johnson PJ. 2013. Trichomonas vaginalis contact-dependent cytolysis of epithelial cells. Infect Immun 81: 1411-1419. https://doi.org/10.1128/IAI.01244-12.

34. Brooks AE, Parsamand T, Kelly RW, Simoes-Barbosa A. 2013. An improved quantitative method to assess adhesive properties of Trichomonas vaginalis to host vaginal ectocervical cells using flow cytometry. J Microbiol Methods 92:73-78. https://doi.org/10.1016/j.mimet.2012.10.011.

35. Phukan N, Parsamand T, Brooks AES, Nguyen TNM, Simoes-Barbosa A. 2013. The adherence of Trichomonas vaginalis to host ectocervical cells is influenced by lactobacilli. Sex Transm Infect 89:455-459. https://doi .org/10.1136/sextrans-2013-051039.

36. Bastida-Corcuera FD, Okumura CY, Colocoussi A, Johnson PJ. 2005 Trichomonas vaginalis lipophosphoglycan mutants have reduced adherence and cytotoxicity to human ectocervical cells. Eukaryot Cell 4:1951-1958. https://doi.org/10.1128/EC.4.11.1951-1958.2005.

37. Sharma H, Tal R, Clark NA, Segars JH. 2014. Microbiota and pelvic inflammatory disease. Semin Reprod Med 31:43-49.

38. O'Hanlon DE, Moench TR, Cone RA. 2011. In vaginal fluid, bacteria associated with bacterial vaginosis can be suppressed with lactic acid but not hydrogen peroxide. BMC Infect Dis 11:200. https://doi.org/10 .1186/1471-2334-11-200.

39. König J, Wells J, Cani PD, García-Ródenas CL, MacDonald T, Mercenier A, Whyte J, Troost F, Brummer R-J. 2016. Human intestinal barrier function in health and disease. Clin Transl Gastroenterol 7:e196. https://doi.org/ 10.1038/ctg.2016.54.

40. Ward PD, Tippin TK, Thakker DR. 2000. Enhancing paracellular permeability by modulating epithelial tight junctions. Pharm Sci Technol Today 3:346-358. https://doi.org/10.1016/S1461-5347(00)00302-3.
41. Lu RY, Yang WX, Hu YJ. 2014. The role of epithelial tight junctions involved in pathogen infections. Mol Biol Rep 41:6591-6610. https://doi .org/10.1007/s11033-014-3543-5.

42. McCole DF. 2013. Phosphatase regulation of intercellular junctions. Tissue Barriers 1:e26713. https://doi.org/10.4161/tisb.26713.

43. Fichorova RN, Buck OR, Yamamoto HS, Fashemi T, Dawood HY, Fashemi B, Hayes GR, Beach DH, Takagi Y, Delaney ML, Nibert ML, Singh BN, Onderdonk AB. 2013. The villain team-up or how Trichomonas vaginalis and bacterial vaginosis alter innate immunity in concert. Sex Transm Infect 89:460-466. https://doi.org/10.1136/sextrans-2013-051052.

44. Guenthner PC, Secor WE, Dezzutti CS. 2005. Trichomonas vaginalisinduced epithelial monolayer disruption and human immunodeficiency virus type 1 (HIV-1) replication: implications for the sexual transmission of HIV-1. Infect Immun 73:4155-4160. https://doi.org/10.1128/IAI.73.7 $.4155-4160.2005$.

45. da Costa RF, de Souza W, Benchimol M, Alderete JF, Morgado-Diaz JA. 2005. Trichomonas vaginalis perturbs the junctional complex in epithelial cells. Cell Res 15:704-716. https://doi.org/10.1038/sj.cr.7290340.

46. Leroy A, Lauwaet T, De Bruyne G, Cornelissen M, Mareel M. 2000. Entamoeba histolytica disturbs the tight junction complex in human enteric T84 cell layers. FASEB J 14:1139-1146. https://doi.org/10.1096/ fasebj.14.9.1139.

47. Lauwaet $T$, José Oliveira M, Callewaert B, De Bruyne G, Mareel M, Leroy A. 2004. Proteinase inhibitors TPCK and TLCK prevent Entamoeba histolytica induced disturbance of tight junctions and microvilli in enteric cell layers in vitro. Int J Parasitol 34:785-794. https://doi.org/10.1016/j.ijpara .2004.03.007.

48. Anaya-Ruiz M, Pérez-Santos JLM, Talamás-Rohana P. 2003. An ectoprotein tyrosine phosphatase of Entamoeba histolytica induces cellular detachment by disruption of actin filaments in HeLa cells. Int J Parasitol 33:663-670. https://doi.org/10.1016/S0020-7519(03)00029-8.

49. Aguirre-García MM, Anaya-Ruiz M, Talamás-Rohana P. 2003. Membrane-bound acid phosphatase (MAP) from Entamoeba histolytica has phosphotyrosine phosphatase activity and disrupts the actin cytoskeleton of host cells. Parasitology 126:195-202. https://doi.org/10 $.1017 /$ S0031182002002767.

50. de Jesus JB, Podlyska TM, Hampshire A, Lopes CS, Vannier-Santos MA, Meyer-Fernandes JR. 2002. Characterization of an ecto-phosphatase activity in the human parasite Trichomonas vaginalis. Parasitol Res 88: 991-997. https://doi.org/10.1007/s00436-001-0583-2.

51. de Miguel N, Lustig G, Twu O, Chattopadhyay A, Wohlschlegel JA, Johnson PJ. 2010. Proteome analysis of the surface of Trichomonas vaginalis reveals novel proteins and strain-dependent differential expression. Mol Cell Proteomics 9:1554-1566. https://doi.org/10.1074/mcp .M000022-MCP201.

52. Štáfková J, Rada P, Meloni D, Žárský V, Smutná T, Zimmann N, Harant K, Pompach P, Hrdý I, Tachezy J. 2018. Dynamic secretome of Trichomonas vaginalis: Case study of $\beta$-amylases. Mol Cell Proteomics 17:304-320. https://doi.org/10.1074/mcp.RA117.000434.

53. Kutuzov MA, Andreeva AV. 2008. Protein Ser/Thr phosphatases of parasitic protozoa. Mol Biochem Parasitol 161:81-90. https://doi.org/10 .1016/j.molbiopara.2008.06.008.

54. Anwar T, Gourinath S. 2016. Deep insight into the phosphatomes of parasitic protozoa and a Web resource ProtozPhosDB. PLoS One 11: e0167594. https://doi.org/10.1371/journal.pone.0167594.

55. Phukan N, Brooks AES, Simoes-Barbosa A. 2018. A cell surface aggregationpromoting factor from Lactobacillus gasseri contributes to inhibition of Trichomonas vaginalis adhesion to human vaginal ectocervical cells. Infect Immun 86:e00907-17. https://doi.org/10.1128/IAI.00907-17.

56. Clark CG, Diamond LS. 2002. Methods for cultivation of luminal parasitic protist of clinical importance. Clin Microbiol Rev 15:329-341. https://doi .org/10.1128/CMR.15.3.329-341.2002.

57. Pfaffl MW, Horgan GW, Dempfle L. 2002. Relative Expression Software Tool (Rest (C) for group-wise comparison and statistical analysis of relative expression results in real-time PCR. Nucleic Acids Res 30:e36. https://doi.org/10.1093/nar/30.9.e36.

58. Clark CG, Diamond LS. 1 August 2010. Lysis of cultured cells for immunoprecipitation. Cold Spring Harb Protoc https://doi.org/10.1101/pdb .prot5466. 